\title{
Adenoid cystic carcinoma of the oesophagus
}

\author{
J.P . O'S U L L I V A N, J.S. C O C K B UR N, \\ and C. E. D R E W
}

St. George's Hospital, London SWI

\begin{abstract}
O'Sullivan, J. P., Cockburn, J. S., and Drew, C. E. (1975). Thorax, 30, 476-480. Adenoid cystic carcinoma of the oesophagus. A case of adenoid cystic carcinoma of the oesophagus occurring in a patient who had previously been treated for craniopharyngioma is presented. This is the thirteenth reported case of adenoid cystic carcinoma of the oesophagus and the first in association with craniopharyngioma. The previously described cases of oesophageal adenoid cystic carcinoma are critically reviewed, and it is suggested that this tumour is in general highly malignant and may not be so rare as is generally thought.
\end{abstract}

Adenoid cystic carcinoma is well known in the major salivary glands and in the oropharynx. It occurs much less commonly in the oesophagus. Because of the tendency to underestimate the number of reported cases an attempt is here made to bring together those cases documented in the English literature. Craniopharyngioma, although not rare, is not a common tumour, and the occurrence of both craniopharyngioma and adenoid cystic carcinoma of the oesophagus in one patient has not, to our knowledge, previously been reported.

\section{CASE REPORT}

A 51-year-old solicitor presented with a six-week history of dysphagia and backache. Solid foods tended to stick half-way, causing pain in the small of the back, and he had lost $2 \mathrm{~kg}$ in weight.

His previous history included craniotomy for a craniopharyngioma (Mr. L. Walsh) seven years previously. A loculated collection of cerebrospinal fluid impinging on the optic chiasma was evacuated, and the capsule of a cystic structure posterior to this was removed. He had radiotherapy postoperatively and did well. Some years before this operation he had been treated for alcoholism. Since craniotomy he had been on corticosteroid and thyroid replacement therapy.

On the present admission physical examination was non-contributory. Barium swallow showed a smoothly outlined filling defect at the junction of the middle and lower thirds of the oesophagus. Oesophagoscopy showed a mucosal bulge, but no tumour was seen. A provisional diagnosis of leiomyoma was made, and the lesion was explored through a right thoracotomy incision. A mobile mass was palpated in the lower oesophagus. The oesophagus and the overlying muscle were incised. A lobulated tumour, $3 \mathrm{~cm}$ in diameter, was found attached by a broad pedicle to redundant mucosa. $\varrho$ A frozen section was reported as squamous car- $\overrightarrow{\overrightarrow{0}}$ cinoma, although a review of the section con- 3 firmed that it was adenoid cystic in histological type. The tumour with its pedicle was excised and? the oesophagus was repaired in two layers with catgut. The chest was closed with drainage to the pleural space.

The patient made a good initial recovery but on $\frac{0}{3}$ the fifth postoperative day he developed a leak. from the oesophagus at the site of the repair. This was confirmed by Gastrografin swallow and the finding of purulent material in the right pleural $\frac{\text { 의 }}{2}$ space on aspiration. Drainage of the right pleural $>$ cavity was begun and intravenous antibiotics were을 given. Over the next three weeks he remained veryn ill with a persistent empyema cavity which re-quired continuous drainage. His condition then ${ }_{0}$ began gradually to improve and in two weeks he was transferred for convalescence. The empyema cavity resolved satisfactorily. Three months aftero

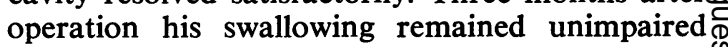
and Gastrografin swallow confirmed an intact $\stackrel{\odot}{?}$ oesophagus with free passage of contrast medium. 7 Oesophagoscopy, performed eight months postoperatively, showed no evidence of residual $\stackrel{\mathbb{\Phi}}{\stackrel{\Phi}{\circ}}$ tumour. He remained well without evidence of $\stackrel{\mathbb{Q}}{\varrho}$ metastases at 11 months. 
HISTOPATHOLOGY In the craniotomy specimen there was a cystic lesion lined by a few layers of squamous cells (Fig. 1). The epithelium was supported by loose connective tissue which showed a mild chronic non-specific inflammatory infiltrate. The appearances were those of a craniopharyngioma.

In the oesophageal specimen the squamous epithelium was stretched over a tumour. There were a few small areas of ulceration, but in no case was there continuity between the tumour and the squamous epithelium. The tumour was composed of cell masses of various sizes. These masses had, in general, a cribriform appearance, the cell groups being broken up into strands and small clumps by a loose fibrous stroma (Fig. 2). This stroma could be seen to communicate with the stroma outside the clumps, and in places it showed cystic degeneration. The cells of the tumour were 'basaloid' with relatively uniform nuclei but with a high mitotic rate. Invasion of muscle was present (Fig. 3) but there was no unequivocal evidence of tumour in the lymphatics or blood vessels in the material examined. The overlying epithelium showed no dysplastic changes. The appearances were those of an adenoid cystic carcinoma of the oesophagus.

\section{DISCUSSION}

In the great majority of cases, carcinoma of the oesophagus is epidermoid in type. A proportion are adenocarcinomas and these mostly arise from rests of heterotopic gastric mucosa. A small number of oesophageal adenocarcinomas, however, are adenoid cystic in pattern, resembling histologically the adenoid cystic carcinoma which occurs in the salivary gland and elsewhere.

In reports of adenoid cystic carcinoma of the oesophagus there has been a tendency to underestimate the number of cases in the literature. For example, Nelms and Luna (1972) reported what they thought was the ninth case, and later in the same year Benisch and Toker (1972) added to the literature what they called the sixth and seventh cases. Azzopardi and Menzies (1962) considered that Marcial Rojas and Vallecillo (1959) had reported the only previous case, but these latter authors said that theirs was the second case and mentioned a third case in the addendum to their paper. Further, they failed to mention the report of Bergmann and Charnas (1958).

Although Jackson (1925) mentions two cases of 'basal celled' carcinoma of the oesophagus, these cannot be accepted as examples of adenoid cystic carcinoma as there are no further details nor are

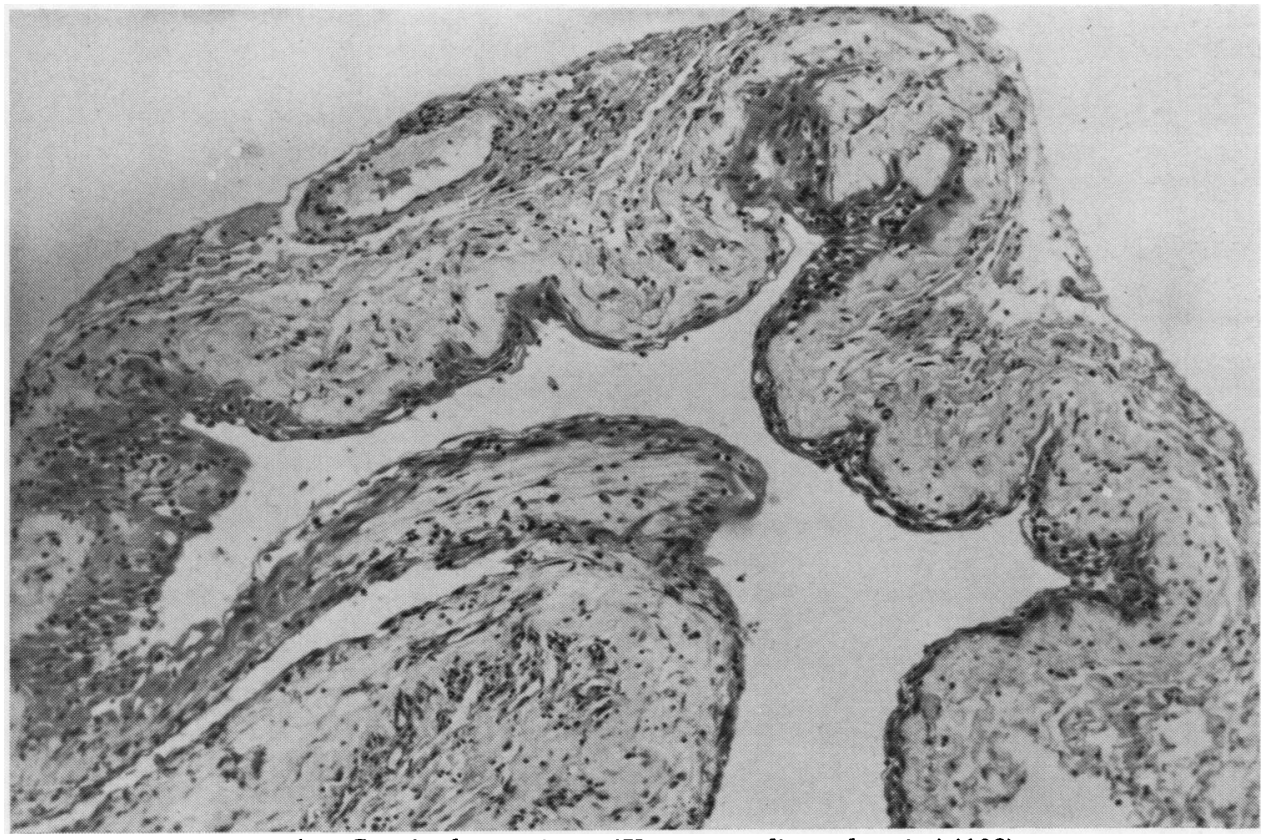

FIG. 1. Craniopharyngioma (Haematoxylin and eosin $\times 108)$. 


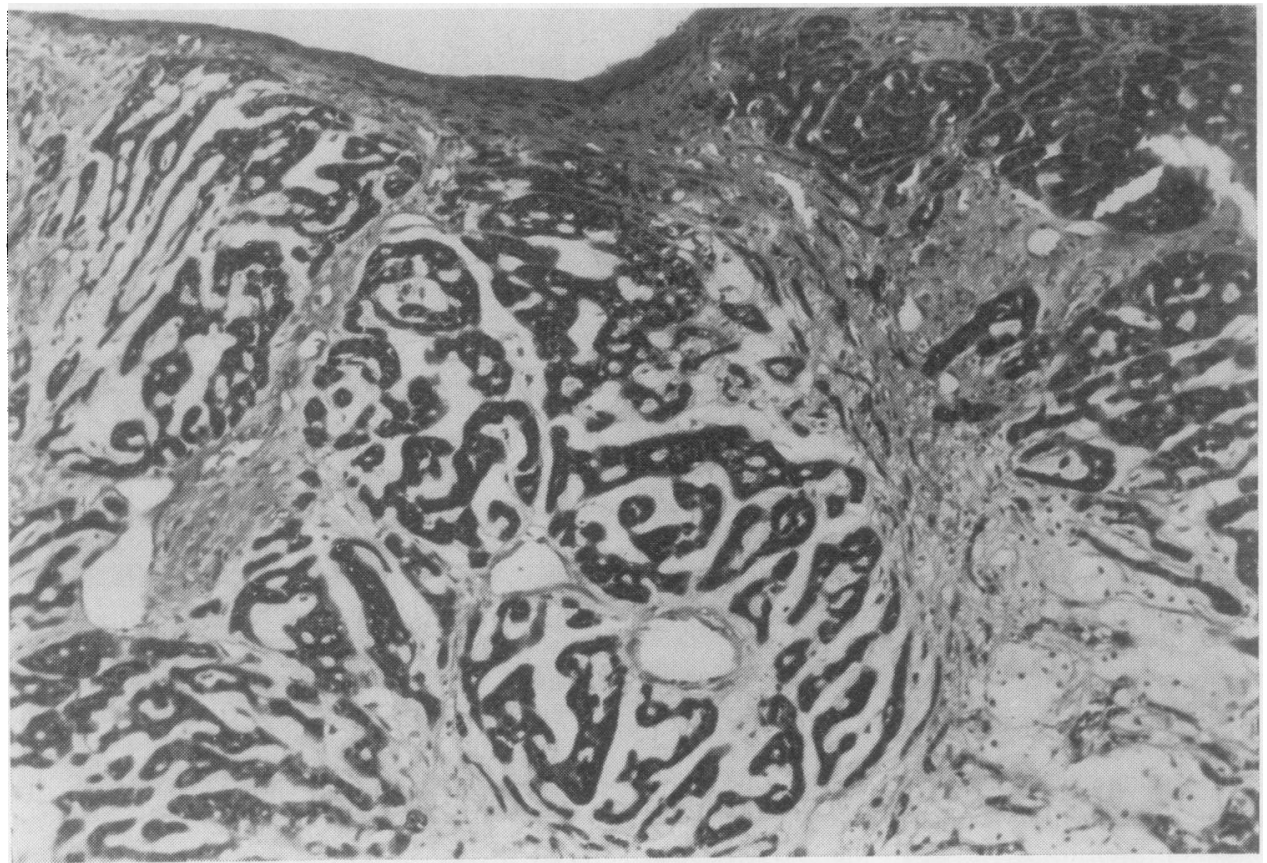

FIG. 2. Adenoid cystic carcinoma showing the typical pattern $(H$ and $E \times 80)$.

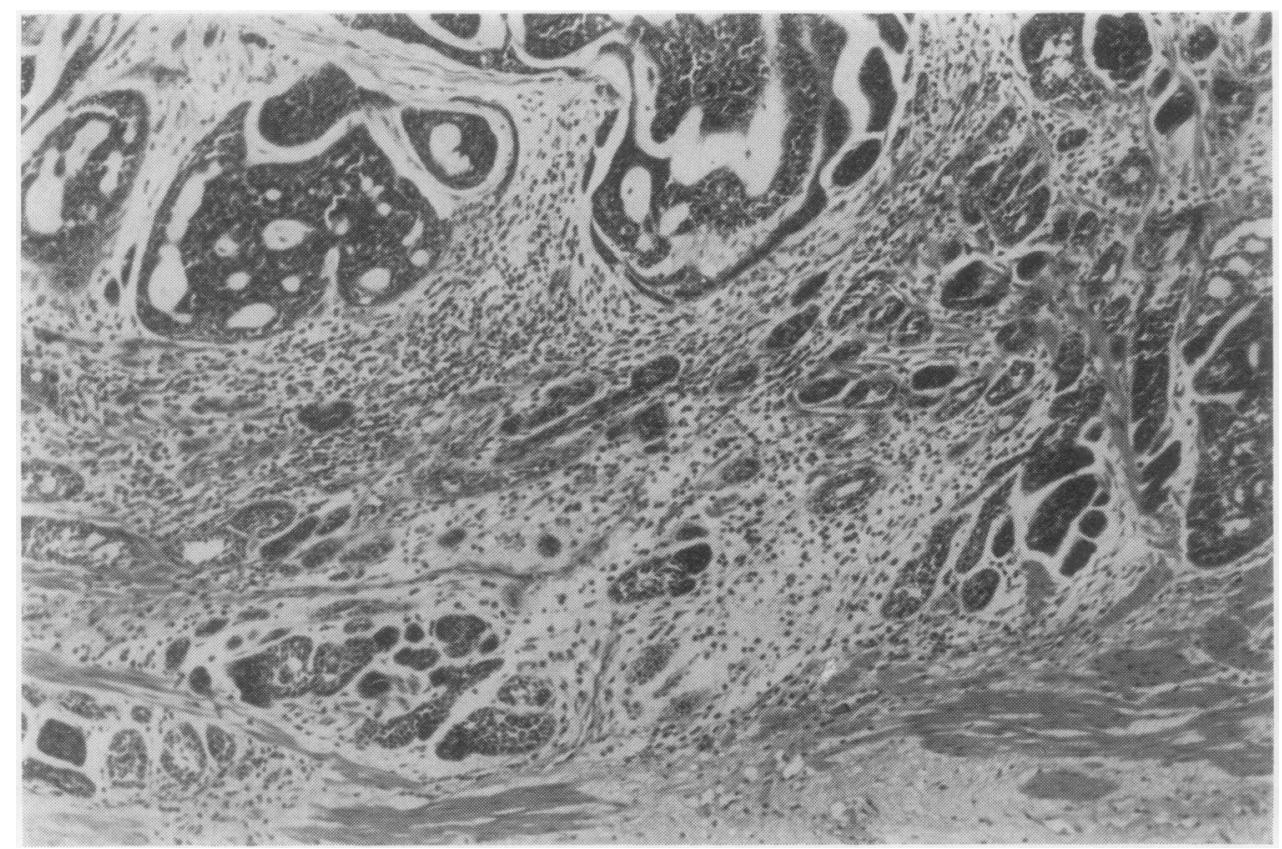

FIG. 3. Adenoid cystic carcinoma showing invasion of muscle $(H$ and $E \times 80)$. 
T A B L E

\begin{tabular}{|c|c|c|c|c|c|c|c|}
\hline Case & Age & Sex & Duration of Dysphagia & Site of Tumour & Metastases & Survival after Operation & Source \\
\hline 1 & 55 & $\mathbf{M}$ & Not stated & Lower & Not stated & Not stated & $\begin{array}{l}\text { United States Naval } \\
\text { Medical School } \\
\text { Color Atlas of } \\
\text { Pathology (1950) }\end{array}$ \\
\hline 2 & 65 & $\mathbf{M}$ & $\begin{array}{l}\text { 'Many years', severe } \\
2 \text { months }\end{array}$ & Middle & Local lymph nodes & Well at 16 days & Bergmann and \\
\hline $\begin{array}{l}3 \\
4 \\
5 \\
6 \\
7\end{array}$ & $\begin{array}{l}51 \\
64 \\
67 \\
57\end{array}$ & $\begin{array}{l}\mathbf{M} \\
\mathbf{F} \\
\mathbf{F}\end{array}$ & $\begin{array}{l}2 \text { montns } \\
6 \text { months } \\
\text { Not stated } \\
6 \text { months } \\
6 \text { months } \\
\text { 'Intermittent' } 5 \text { years, } \\
\text { 'progressive' few }\end{array}$ & $\begin{array}{l}\text { Middle } \\
\text { Middle } \\
\text { Lower } \\
\text { Middle } \\
\text { Middle }\end{array}$ & $\begin{array}{l}\text { Widespread } \\
\text { Not stated } \\
\text { Not stated } \\
\text { Not stated } \\
\text { Widespread }\end{array}$ & $\begin{array}{l}18 \text { months; died } \\
\text { Well at } 2 \text { weeks } \\
1 \text { day; died } \\
10 \text { days; died } \\
2 \text { years; died }\end{array}$ & $\begin{array}{l}\text { Marcial Rojas and } \\
\text { Vallecillo (1959) } \\
\text { Azzopardi and } \\
\text { Menzies (1962) }\end{array}$ \\
\hline $\begin{array}{r}8 \\
9 \\
10 \\
11\end{array}$ & $\begin{array}{l}62 \\
54 \\
72 \\
68\end{array}$ & $\begin{array}{l}\mathbf{F} \\
\mathbf{M} \\
\mathbf{M} \\
\mathbf{M}\end{array}$ & $\begin{array}{l}\text { months } \\
4 \text { months } \\
2 \frac{1}{2} \text { months } \\
2 \text { months } \\
4 \text { months }\end{array}$ & $\begin{array}{l}\text { Middle } \\
\text { Middle } \\
\text { Upper } \\
\text { Middle }\end{array}$ & $\begin{array}{l}\text { Not stated } \\
\text { Regional nodes } \\
\text { None } \\
\text { Not stated }\end{array}$ & $\begin{array}{l}\text { Well at } 11 \text { months } \\
2 \text { months; died } \\
4 \text { days; died } \\
\text { Died in 'immediate }\end{array}$ & $\begin{array}{l}\text { Raphael et al. (1966) } \\
\text { Nelms and Luna (1972) } \\
\text { Benisch and Toker }\end{array}$ \\
\hline $\begin{array}{l}12 \\
13\end{array}$ & $\begin{array}{l}65 \\
51\end{array}$ & $\begin{array}{l}\mathbf{F} \\
\mathbf{M}\end{array}$ & $\begin{array}{l}18 \text { months } \\
6 \text { weeks }\end{array}$ & $\begin{array}{l}\text { Lower } \\
\text { Lower }\end{array}$ & $\begin{array}{l}\text { Widespread } \\
\text { None found }\end{array}$ & $\begin{array}{l}2 \text { years; died } \\
\text { Well at } 11 \text { months }\end{array}$ & Present case \\
\hline
\end{tabular}

they illustrated. The first case to be so named appeared in the United States Naval Medical School Color Atlas of Pathology (1950). It is probable that this is the same case as the "cystic basal-cell cancer of the oesophagus' which Geschickter illustrated in 1935 , since he edited the relevant section of the Atlas and there is the same number of cases of adenocarcinoma of the oesophagus in his series in each publication.

Cases reported subsequently are summarized in the Table. The cases of Lortat-Jacob et al. (1968) are not included because there is no full histological description.

Of the acceptable cases of oesophageal adenoid cystic carcinoma, the tumour is slightly commoner in men $(7: 5)$. The age range is $51-72$ years, almost half the patients being in their fifties. The majority of the tumours have occurred in the mid-oesophagus and most patients had dysphagia for two to six months preoperatively. The prognosis is poor. Of the patients who survived the immediate postoperative period, none has survived longer than two years and all of these are reported to have had widespread metastases.

The histogenesis of the tumour is still in dispute. Mainly on the basis of the (then) extreme rarity of the tumour, Bergmann and Charnas (1958) suggested that it arose from tracheobronchial rests in the oesophagus. Most other authors have considered that it arises from the deep submucosal oesophageal glands. These are derived from stratified squamous epithelial outgrowths which have penetrated the submucosa, and their ducts are lined by stratified cuboidal epithelium. Thus, on purely morphological grounds, these glands are worthy of consideration as the basis of the adenoid cystic carcinoma. Benisch and Toker (1972) suggest that the tumour may arise from either the surface or the adnexal epithelium. Although their argument is unconvincing (and is anticipated by Bergmann and Charnas (1958), whom they do not quote), it is interesting that the tumour established continuity with the surface epithelium over minute areas in two of Azzopardi and Menzies' (1962) cases.

The most unusual feature of the patient here reported is the occurrence of both craniopharyngioma and adenoid cystic carcinoma of oesophagus. Cranio-pharyngioma accounts for about $3 \%$ of all intra-cranial tumours and is usually said to arise from squamous rests in the pars tuberalis of the pituitary. There are certain superficial similarities between the two tumours. Both are cystic, although the cysts are microscopic in the carcinoma and tend to be macroscopic in the pituitary tumour. In both cases, the 'type' cell of the tumour has similarities to the basal cell of the skin. In the adenoid cystic carcinoma this resemblance is spurious and in the craniopharyngioma maturation to a squamoid cell type is common. However, the tumours differ radically in their behaviour; craniopharyngioma, though it compresses surrounding structures, very rarely infiltrates and has not been reported to metastasize, in contrast to the described behaviour of adenoid cystic carcinoma of the oesophagus.

Tumours with an adenoid cystic growth pattern occur most commonly in the salivary gland. Less commonly, they arise from the bronchus, breast, skin, and vulva as well as the oesophagus. The behaviour of the tumour very much depends on the site of origin. In the salivary gland it is always malignant and is capable of distant metastases (Hertig, 1957). Bronchial adenoid cystic carcinomas grow slowly, infiltrating contiguous structures, and metastasize late. The rare adenoid cystic 
carcinoma of the breast metastasizes very uncommonly. Whereas adenoid cystic tumours of skin are on the whole benign tumours, adenoid cystic carcinoma of the vulva is highly malignant and difficult to cure.

Too few cases of adenoid cystic carcinoma of the oesophagus have been reported to allow the behaviour of the tumour to be predicted with certainty. However, in all cases in which the histopathology is adequately described the tumour is seen to be locally infiltrative. Three patients have died with widespread metastases and two others have had lymph node involvement at the time of oesophagectomy. It seems likely, therefore, that this tumour tends to metastasize more quickly than its salivary gland counterpart, and to have a worse prognosis.

In the present case treatment consisted of local excision of the tumour. It is questionable whether a more radical excision is justified in the light of the poor prognosis of the previously reported cases. It is not known whether radiotherapy is indicated postoperatively. Overall, there is little doubt that the outlook in adenoid cystic carcinoma of the oesophagus is as poor as in the usual epidermoid oesophageal carcinoma.

We wish to thank Mr. L. S. Walsh for permission to publish details of the patient's initial admission, and Dr. K. E. Jefferson for the radiological reports. We wish also to thank Miss I. J. Underhill for the preparation of the photographs.

\section{REFERENCES}

Azzopardi, J. G. and Menzies, T. (1962). Primary oesophageal adenocarcinoma. Confirmation of its existence by the findings of mucous gland $\overrightarrow{\bar{c}}$ tumours. British Journal of Surgery, 49, 497.

Benisch, B. and Toker, C. (1972). Esophageal carcinomas with adenoid cystic differentiation. Archives of Otolaryngology, 96, 260.

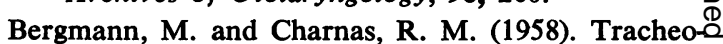
bronchial rests in the esophagus. Their relation toon some benign strictures and certain types of cancer of the esophagus. Journal of Thoracic $\overrightarrow{0}$ Surgery, 35, 97.

Geschickter, C. F. (1935). Tumours of the digestive $\vec{\omega}$ tract. American Journal of Cancer, 25, 130.

Hertig, P. (1957). Histologie und Prognose der Zylindrome. Oncologia (Basel), 10, 91.

Jackson, C. (1925). Carcinoma and sarcoma of thei esophagus: a plea for early diagnosis. Americant Journal of the Medical Sciences, 169, 625.

Lortat-Jacob, J.-L., Maillard, J. N., Richard, C. A.,음 Fékété, F., Huguier, M., and Conte-Marti, J. (1968). Primary esophageal adenocarcinoma: $\rightarrow$ report of 16 cases. Surgery, 64, 535.

Marcial Rojas, R. A. and Vallecillo, L. A. (1959) Primary adenoidcystic carcinoma of the esophagus. Report of one case and review of the $\overrightarrow{0}$ literature. Archives of Otolaryngology, 70, 197. ov

Nelms, D. C. and Luna, M. A. (1972). Primary adenocystic carcinoma (cylindromatous carcinoma) of the esophagus. Cancer, 29, 440.

Raphael, H. A., Ellis, F. H., and Dockerty, M. B.o (1966). Primary adenocarcinoma of the eso-0 phagus: 18-year review and review of literature. Annals of Surgery, 164, 785.

United States Naval Medical School (1950). Color Atlas of Pathology, p. 295, J. B. Lippincott, Philadelphia.

Requests for reprints to: Dr. J. P. O'Sullivan Department of Histopathology, St. George's Hospital, London SW1. 